\title{
Órfãos na capitania do \\ Ceará: entre a lei e as práticas coloniais
}

\author{
Patrícia Marciano de Assis*
}

patriciamarcia@outlook.com

\section{Resumo}

Neste artigo, buscamos refletir sobre a relação entre as Ordenações Filipinas e as práticas na Capitania do Ceará. Desse modo, consideramos suas especificidades próprias a partir da seleção dos inventários e autos de querela entre 1799 e 1822 . Aquele primeiro marco, diz respeito ao momento em que essa Capitania emancipa-se da de Pernambuco, angariando estruturas administrativas próprias; e esse último recorte refere-se ao fim do período denominado de colonial, quando podemos evidenciar algumas modificações na própria concepção de órfão. Desse modo, percebemos que tanto na legislação quanto na prática, eram os juízes de órfãos os responsáveis pelo direcionamento dos órfãos, que encarregava os tutores e curadores do cuidado das pessoas e bens dos órfãos, respectivamente. Mas pudemos vislumbrar que as próprias condições locais acabavam colocando as questões dos órfãos entre a lei e as práticas coloniais, inclusive suas organizações familiares.

\section{Palavras-chave}

Órfãos; Juízes de órfãos; Ordenações Filipinas

\section{Orphans in the capitania of Ceará: between law and colonial practices}

\begin{abstract}
In this article we seek to reflect on the relationship between the Philippine Ordinances and the practices in the Captaincy of Ceará, in this way we consider their specific specificities from the selection of inventories and case files between 1799 and 1822. That first landmark refers to the moment in which this Captaincy is emancipated from that of Pernambuco, collecting its own administrative structures; and this last cut refers to the end of the so-called colonial period, when we can evidence some modifications in the orphan's own conception. In this way, we realized that both in law and in practice, it was the orphans judges who were responsible for directing the orphans, who entrusted the care of the orphans and the care of the orphans, respectively. But we could glimpse that local conditions themselves ended up putting questions of the orphans between law and colonial practices, including their family organizations.
\end{abstract}

\section{Keywords}

Orphans, Orphans Judges, Philippine Ordinances. 
"A relação que encontramos entre aquilo que lemos nos textos legais e o que efetivamente se pratica é muitas vezes remota e vaga, se não redondamente contraditória." (Formação do Brasil Contemporâneo - Caio Prado Júnior, 1999, P. 301)

De acordo com Caio Prado, há certa distância entre o que se pratica e o que é proposto nos textos legais. Dessa forma, as questões que, por ora nos assaltam, dizem respeito ao que têm de comum entre a visão das Ordenações Filipinas ${ }^{1}$, os inventários e os estudos empreendidos sobre o Brasil e as práticas da Capitania do Ceará: como se organizou a capitania nos assuntos referentes aos órfãos? Como e onde eles apareciam? Quais questões os envolviam?

De acordo com Bicalho (2000), a elaboração desse conjunto de leis iniciou-se em 1583, no reinado de Felipe I, mas só entrou em vigor no de Felipe II, em 1603 , sendo composto por cinco livros, versando sobre justiça, relação entre Estado e Igreja, ações cíveis e criminais, direito privado e individual, e os dois últimos sobre direito penal. Dentre as ordenações, essas foram as primeiras a destinar um juízo privativo aos órfãos, isto é, um juiz específico para tratar dos assuntos a eles referentes, notadamente relacionado à ideia de preservação do pátrio poder. Assim, no Título LXXXVIII - "Dos Juízes dos Orfãos" - estava proposto e ordenado o aparato administrativo desse juizado: "ordenados os Officios de Juiz e Scrivão dos Orfãos, para specialmente proverem nas pessoas e fazendas deles, no que devem ter grande cuidado, pela muita confiança, que nelles he posta" (CÓDIGO FILIPINO, 2004, p. 206). Dentre outras especificações, aos tutores caberia "proverem" preferencialmente as pessoas dos órfãos e aos curadores, seus bens.

Tentando entender as especificidades e formas de organização desse juizado no Ceará colonial é que questionamos o modo de formação das relações sociais, as propostas a esse respeito nas Ordenações e as práticas presentes nos inventários. O pressuposto principal é que a ideia de 'órfão' foi uma categoria historicamente construída e que, no período colonial, esteve relacionada à criação desse juízo privativo a partir da legislação lusa, vigente dentro de um quadro maior de expansões marítimas, explorações e ocupações coloniais, e das práticas dos juízes nas diversas localidades, dentro de um processo de ocupação e povoamento dos territórios da América Portuguesa.

O interesse na temática e na escolha das fontes está em consonância com as discussões dos pesquisadores da História da Família, os quais apontam - principalmente nos últimos anos - para a importância de pensar a família e seu papel não só na organização social mas também econômica e política dos diversos períodos históricos (Cf. SCOTT, 2014; FARIA, 1997). Considerando os silêncios historiográficos acerca da organização do juizado de órfãos e da construção dessa categoria, bem como visando a contribuir para as reflexões sobre a família no período colonial, buscaremos, neste artigo, compreender as condições da Capitania do Ceará e da distribuição das documentações do período colonial, sobreviventes às seleções do tempo e dos demais sujeitos envolvidos, sobretudo, a partir da ideia de que a história dos órfãos no Ceará deve ser lida a partir de uma documentação

${ }^{1}$ Citamos de dois modos diferentes ao longo do texto, Almeida (2004), para nos referirmos ao comentador Cândido Mendes, cujo conteúdo é de 1870, e Código Filipino (2004), para referenciar a lei em sua edição fac-similada de 1603. 
própria, dentro do período colonial local, que se insere no contexto geral da América Portuguesa.

A documentação analisada ${ }^{2}$, especificamente referentes aos órfãos, está disponível no Arquivo Público do Estado do Ceará e diz respeito a dois conjuntos gerais: um cartorial, com inventários de bens, registros de saída e entrada de dinheiro dos órfãos e correspondências anexadas a esse respeito; e outro de processo criminal, aqui citado em menor escala, composto pelos Autos de Querela e Denúncia. No primeiro caso, é possível acompanhar o processo de atribuição de tutores e curadores durante a partilha de bens, mas também alguns ofícios referentes ao cumprimento ou não dessas ordens ao final de cada maço, daí ser o principal elemento dessa reflexão. No segundo, também conseguimos encontrar tais atribuições, mas dentro de outra lógica que é desenrolada após a ocorrência de crimes. O uso desses dois conjuntos para o estudo dos órfãos é importante por contribuir para a ampliação do estrato social analisado pelo historiador, tendo em vista que, respectivamente, eles dizem respeito às tutorias $\mathrm{e}$ curadorias daqueles que possuíam bens inventariados e dos outros que não eram visíveis por meio dessas partilhas. Nesse sentido, embora o segundo não seja citado constantemente nesse texto e nem seja seu objeto principal, ele está sendo considerado na nossa discussão.

O objetivo deste artigo é confrontar os dispositivos legais referentes aos Órfãos, tutores e curadores, com sua prática na realidade da capitania do Ceará no período colonial. Com esse intuito, dividimos o artigo em duas partes, a partir das quais discutiremos, no primeiro tópico, sobre as atribuições dos juízes de órfãos segundo a legislação lusa, o perfil dos órfãos da Capitania do Ceará e a documentação que o envolve, para, em seguida, tratarmos das formações sociais presentes, dando ênfase aos personagens que giram em torno do processo da orfandade colonial e as estruturas familiares. Finalizamos com breves considerações acerca desse estudo.

\section{Os juízes e os órfãos: reformulações do pátrio poder}

O processo de ocupação da capitania do Ceará deuse de forma tardia, em relação aos congêneres da América Portuguesa, ocorrendo entre o final do século XVII e início do XVIII, com o avanço do açúcar e expulsão do gado para o interior. Isso explica em parte o maior número da documentação conforme passam os anos iniciais do século XVIII, a partir da criação de novas vilas e desenvolvimento das outras.

Nesse sentido, Girão (1984) sugere que o surgimento dos núcleos urbanos e de mudanças socioeconômicas e políticas foram propiciados pela Indústria do Charque. As décadas seguintes a esse primeiro momento também teriam sido um período intenso de transformações, a partir das quais vemos a articulação de aspectos familiares com o domicílio e com a violência, além das constantes secas. De acordo com Vieira Júnior (2004, p. 12), “A vida nas áreas urbanas se intensificou havendo um significativo crescimento populacional; concomitantemente, a metrópole apostava na criação e proliferação das vilas enquanto forma de disciplinar a população $\mathrm{e}$ implementar estruturas administrativas e de fisco". 
Entretanto, até 1799, a Capitania do Ceará estava vinculada à de Pernambuco, inclusive em suas questões administrativas, sobretudo as de comércio e as jurídicas, mas emancipou-se nessa data e, grosso modo, alguns autores colocam que: "A partir de 1780 estava efetivada a colonização do seu território, com a pacificação das tribos indígenas e a fundação de várias vilas pelo Sertão" (VIEIRA JÚNIOR, 2004, p. 12). Com a criação de vilas e todas essas modificações, tomamos como marco esse ano de 1799, principalmente por conta da emancipação da capitania, como um elemento significativo para a compreensão de questões acerca dos órfãos, que vemos emergir em meio ao desenvolvimento econômico, as cíclicas das secas e as violências inter e intrafamiliares na capitania do Ceará. Visto que, conforme ela crescia em importância, aumentava sua visibilidade ante a Metrópole, que cuidava em estabelecer seu controle, sobretudo, legislativo, onde "o aparelhamento do Estado vai se organizando melhor, no disciplinamento das energias de uma sociedade que se desenvolve" (MENEZES, 1966, p. 353).

Com o desenvolvimento das atividades comerciais e de povoamento local com fundação de vilas, ocorreu a criação dos cargos de juízes ordinários por volta de 1759. Esses juízes, segundo as Ordenações Filipinas, tinham como escopo "trabalhar, que nos lugares e seus termos, onde forem Juízes, se não façam malefícios, nem malfeitorias. E fazendo-se, provejam nisso, e procedam contra os culpados com diligencia" (CÓDIGO FILIPINO, 2004, p. 134). Segundo Almeida (2004, p. 206), “a jurisdição destes Juizes se regula pela divisão territorial" e a eles cabiam a feitura das partilhas e das demais atividades:

Antigamente o prover sobre pessoas $e$ fazendas dos Orfãos pertencia aos Juizes ordinários e Tabelliães, e por suas ocupações serem muitas, e não poderem cumprir com esta obrigação, como deviam, foram ordenados os Officios de Juiz e Scrivão dos Orfãos, para specialmente proverem nas pessoas $e$ fazendas deles, no que devem ter grande cuidado, pela muita confiança, que nelles he posta. E em todas as villas e lugares, onde nelles e no termo houver quatrocentos visinhos, ou dahi para cima, mandamos que haja Juiz dos Orfãos apartado. E onde não houver o dito numero de visinhos, os Juizes ordinários sirvam o Officio de Juiz dos Orfãos com os Tabelliães da villa [...].

Isto é, eles foram responsáveis pelo cumprimento da legislação vigente atuando em diversos assuntos enquanto não havia juízes próprios, especificamente isso pode ser exemplificado para o caso dos órfãos, os quais estavam a seu cargo até a criação dos Juízes de órfãos. Como suporte a este, ou mais diretamente, da necessidade de responder a uma demanda local referente à administração dos assuntos dos órfãos, vemos emergir o tal juiz, uma vez que: "O crescimento da população do Brasil, e suas especiaes circumstancias movêrão o governo da Metropole á crear nas villas, onde houvessem Juizes Ordinarios, Juizes de Orphãos triennaes, consignando-lhes um regimento que foi promulgado com o Al. de 2 de Maio de 1731"(ALMEIDA, 2004, p. 206).

Sobre a categoria "órfão", encontramos algumas caracterizações que mostram, através do Direito Português, como o pai tinha poder sobre os filhos, o pátria potestas, até que eles atingissem 25 anos, casassem ou se emancipassem, pois "Com o falecimento paterno, os filhos menores de 25 anos adquiriam a nomeação de órfãos sendo assim identificados até que atingissem a maioridade pelos caminhos jurídicos" (MORENO, 2007, p. 72). De acordo com Freyre (2000), na sociedade colonial, as mulheres e os filhos permaneciam submetidos socialmente ao pátrio poder, o que explica não só a importância da criação de um juiz específico para 
administrar esse poder, quando da morte dos pais, em cidades e vilas com considerável contingente populacional, quanto as diferenças presentes no tratamento dessa questão em consonância com os sujeitos envolvidos. Conforme sugeriu Brugger (2007, p. 47), mesmo considerando as críticas da historiografia a ideia de patriarcalismo, é notável nesse período o domínio masculino sobre a organização da família em diferentes espaços: "No Brasil, além de este poder se manifestar sobre o espaço doméstico - não era necessariamente restrito ao parentesco consangüíneo, mas englobando em seu universo escravos e agregados - ele se desdobra na esfera política".

Quanto ao juizado, como ressaltou Gallo (2000), é importante salientar que houve toda uma forma de relação com esses cargos, inclusive de venda, que dizia respeito à própria maneira como eles eram praticados, notadamente em benefício próprio. Em outra ocasião, explicitamos como o trato com os bens dos órfãos por eles administrados, isto é, dos bens herdados por inventários por ocasião da morte do pai ou da mãe, os quais ficavam a cargo dos juízes de órfãos, passavam por uma série de transações econômicas e apropriações em benefício daqueles que tinham a obrigação por lei de preservá-los, os mesmos, tais como as práticas de empréstimos dos próprios juízes ou as vendas de propriedades e objetos pelos curadores (Cf. ASSIS, 2013).

$\mathrm{Na}$ Capitania do Ceará, a criação de um cargo específico para cuidar dos negócios dos órfãos esteve intimamente relacionada à emancipação da de Pernambuco, já que, enquanto ela estava administrativamente subordinada, era nessa última que as estruturas e cargos eram organizados, muitas vezes aquém dos interesses locais. Fazendo uma leitura de alguns documentos anteriores a esse período, vemos diversos apontamentos sobre a condição local que, segundo o Ouvidor Abelar Barbelo (2005, p. 16), em 1787, ainda estava em vias de colonização e organização do trabalho: “A capitania do Ceará (...) jas ainda quazi toda inculta e dezaproveitada, e se pode dizer que se acha ao dia de hoje em principios de sua povoação..."; e que "Metade dos habitantes desta Comarca são vadios sem oficio, ou vagabundos por natureza...”.Segundo Pinheiro (2005, p. 15), a organização colonial ainda era, de fato, incipiente nesse período, pois: “A estrutura jurídica se restringia à ouvidoria e aos juízes ordinários, eleitos no âmbito das vilas junto com as Câmaras de vereadores, permitindo que muitas questões fugissem da sua alçada". Uma das que fugiam era exatamente aquela que previa a criação desse juizado.

Foram, inclusive, os apontamentos desse estado e a falta de cumprimento das leis lusas que justificaram o pedido de emancipação que, de acordo com o então Governador Bernardo Manoel Vasconcelos e outras autoridades do período, seria uma maneira de solucionar o 'abandono' e a falta de organização colonial, bem como, criar uma demanda por novos cargos e arrecadações:

$$
\begin{aligned}
& \text { A desgraça com que se cobre, aquella } \\
& \text { importante collonia, emquanto a mim, he } \\
& \text { a mais principal, não ter huma } \\
& \text { navegação directa a Capital de Lisboa, } \\
& \text { pois como os seus gêneros se recebem } \\
& \text { por Pernambuco, se reputão a maior } \\
& \text { parte delles, legítimos de Pernambuco, } \\
& \text { não merecendo por isso o Siará, a menor } \\
& \text { contemplação, nem o menor empenho, } \\
& \text { que facilite o seu aumento... (BARBELO, } \\
& \text { 2005, p. 16). }
\end{aligned}
$$

Além de outros argumentos, o estado em que se encontrava a Capitania era a principal maneira de comprovar a necessidade de estabelecer uma navegação direta da Capitania do Ceará com Lisboa, entre o desenvolvimento e criação do aparato administrativo local, tendo em vista que o objetivo da colonização e da 
arrecadação de verbas estavam, por hora, impedidos pela predominância de um estado de 'vagabundagem'. De acordo com Pinheiro (2005), o conjunto de memórias da qual os documentos supracitados fazem parte, os quais tratam das últimas décadas do século XVIII, tem importante papel como testemunho de todo um processo de transformação que estava em curso, sobretudo com a morte de D. José I, a queda do Marquês de Pombal e o novo Governo de Dona Maria. Essa última foi quem realizou uma série de reformas que alteraram a relação da Metrópole com a Colônia, sendo substituída por seu filho D. João, denominado príncipe regente, em 15 de julho de 1799, por conta da loucura da mãe, que prosseguiu com várias mudanças.

Ora, se nosso intuito é o de observar a relação da documentação encontrada na Capitania com as Ordenações de Portugal, optamos por realizar uma análise após a emancipação dessa Capitania, pois, a partir desse recorte inicial, podemos observar mais de perto, sem a necessidade de recorrer aos documentos presentes em Pernambuco, como funcionava o aparato jurídico na capitania do Ceará, agora emancipada, bem como em que medida havia, ou não, uma coincidência entre a lei e prática propostas pelas leis lusas. De 1799 nossa pesquisa se estende até 1822 , a fim de delimitar nosso estudo no período compreendido como colonial; visto que, a partir dessa data, há indícios de novas reorganizações administrativas, a partir das quais pesquisas sugerem movimentações no sentido de maior atuação do Estado em campos, como a educação, que acabam por modificar o foco das ações sobre os órfãos.

Dentre o aparelhamento do Estado, destacamos aquele referente ao juizado de órfãos, surgido oficialmente em 1731, composto por escrivão, juiz, tabelião, provedor e ouvidor. Como ressaltou Vainfas, ele fazia parte de um conjunto de cargos da justiça do período colonial que visava a ampliar a autoridade metropolitana: "Havia também os juízes de vintena, os juízes dos órfãos, os juízes ordinários e os juízes de fora. (...) Essa ampliação da malha judiciária objetivou fortalecer a autoridade da Coroa, através do alargamento dos canais de provimento de justiça régia" (VAINFAS, 2001, p. 18). Segundo Cardozo (2010), nesse caso específico, “O Juizado de Órfãos [...] foi instalado no Brasil para regularizar o universo das famílias que possuíssem menores de idade como seus integrantes".

Assim, a esses juízes cabia o cuidado daqueles definidos como órfãos, dentro da perspectiva de que não possuíam condições de gerir seus bens e pessoas, isto é, o "menor de vinte cinco anos (...) quando lhe morre pai, ou mai" (CÓDIGO FILIPINO, 2004, p. 209). Inclusive, é importante ressaltar aqui o fato de que há uma relação confusa entre o "ser órfão" (isto é, o período em que a pessoa era considerada órfã) e o de "menor" (referente aqueles que não atingiram a idade de 25 anos), ou seja, nem todo menor era considerado órfão - embora o menor incapaz também assim fosse denominado -, mas todo aquele considerado órfão era um menor de idade.

Ademais, é importante destacar que se tratava de uma categoria jurídica, criada dentro de condições específicas e ligadas a condicionantes sociais, de maneira que, por lei, nessa categoria, estariam todos aqueles que perderam pai ou mãe, com menos de 25 anos e solteiros. Nesse último caso, o pressuposto era que o matrimônio estava relacionado diretamente a uma mudança da relação com o poder paterno representado pelo juiz, como no caso das mulheres que, após casadas, estavam socialmente sob a tutela dos maridos. Embora, como salientou Silva (2010, p. 64), outras variáveis do mesmo tipo incidissem sobre a atuação dos juízes, já que, dentro da mesma perspectiva e considerando os envolvidos, "No caso do falecimento 
da mãe e permanência do pai, o infante com idade inferior a 21 anos não era considerado juridicamente órfão e sim menor, ou seja, a condição de órfão estava atrelada à ausência do pai".

Quanto a atuação prevista por lei para os juízes de órfãos, de acordo com Graça Salgado (1985, p. 262263), além de serem nomeados pelo rei para o período de três anos e possuírem idade acima de trinta anos, eles deveriam realizar algumas atividades específicas:

1. Cuidar dos órfãos, de seus bens e rendas; 2. Fazer um levantamento do número de órfãos do lar; 3. Elaborar, com o escrivão dos Órfãos, um livro onde constarão o nome de cada órfão, filiação, idade, local de moradia, com quem mora, tutor e curador, bem como o inventário de seus bens móveis e de raiz e o estado em que se encontram; 4. Fazer que os culpados por danos aos bens dos órfãos paguem por seus crimes; 5 . Inventariar os bens dos defuntos que deixarem filhos menores de 25 anos; 6. Avaliar, com o escrivão dos Órfãos e outras pessoas juramentadas, os bens pertencentes aos órfãos que estiverem em processo de inventário ou partilha; 7. Entregar os órfãos menores e desamparados a pessoas capazes de cria-los, determinando que estas recebam o necessário ao seu sustento; 8. Fazer pregão dos [...] órfãos maiores de sete anos, que forem dados por soldada; 9. Garantir o necessário ao mantimento, vestuário, calçado e tudo o mais dos órfãos que não forem dados por soldada, mandando registrar os gastos do inventário; 10. Mandar ensinar a ler e escrever aos órfãos, que tiverem qualidade para isto, até a idade de 12 anos; 11. Fiscalizar a atuação dos tutores e curadores em relação aos bens dos órfãos; 12. Conceder aos órfãos licença para casarem e cartas de suprimento de idade; 13. Depositar o dinheiro dos órfãos numa arca com três chaves, que ficarão com o juiz de Órfãos, o depositário e o escrivão dos Órfãos; 14. Ter jurisdição em todos os feitos cíveis em que os órfãos estiverem envolvidos, enquanto não forem emancipados ou casados; 15. Ter jurisdição sobre os feitos cíveis movidos pelos órfãos contra os que administrarem mal seus bens; 16 . Fazer a partilha dos bens dos órfãos.
Tais atribuições fazem-se presentes na documentação aqui trabalhada, revelando um esforço por parte das autoridades locais de seguir com as ordens do rei, já que elas se encontravam nas Ordenações que especificavam sua atuação, embora nem sempre as condições locais permitissem.

Para melhor explicitar essa relação do que é proposto com os vestígios deixados sobre a Capitania do Ceará, a documentação de que hora tratamos dividese pelas localidades da comarca do Ceará Grande em: Aracati, Fortaleza, Aquiraz, Icó e Crato (especificamente Jardim e Milagres). Elas estão divididas em dois fundos de um mesmo conjunto cartorial, no Arquivo Público do Ceará, um catalogado e outro ainda em vias de catalogação, respectivamente, Cartório de Órfãos de Fortaleza e Cartório de Aracati, além dos Autos de Querela, presente em outro conjunto documental, apenas citados esporadicamente nesse artigo.

Essas localidades pertencentes à Capitania do Ceará tiveram papéis importantes em diversos aspectos da história local. Segundo o Ouvidor Pinto de Avelar Barbelo, sua importância comercial cresceu com a extinção da Companhia de Pernambuco:

As suas villas em numero de doze,
excluindo a do Aquiraz, a da Fortaleza, e
do Icó, que são de huã datall anterior
todas ellas, menos as dos indios,
vizivelm.te são filhas da propagação do
Comercio, e creadas desde o anno de
1770 para cá, em que o mesmo
principiou a dilatar se algum tanto neste
pais.(BARBELO, 2005, p. 44).

Com isso ele quis demonstrar como os lucros referentes ao comércio aumentariam quando do comércio direto e ressaltou, desse modo, a importância anterior de três das vilas presentes na documentação cartorial no Ceará. Todas as supramencionadas constam na tabela Mapa das Vilas e principaes Povoaçoens de 
Brancos, e Índios da Capitania do Ceará Grande com as denominações das ditas Vilas, e invocaçoens dos Oragos das suas respectivas Matrizes e Capelas. Feito em primeiro de abril de 1783 como vilas de brancos, a saber, V.a ${ }^{3}$ da Fortaleza, V.a Aquiraz Cabeça de Comarca, V.a de S.C de Aracati (1748), V.a do Icó (1738) e V.a Real do Crato (1764), respectivamente com seus Oragos das suas Matrizes N. S. d'Assumpção e S. José de Ribamar, S. José de Ribamar, N. S. do Rosário, N. S. da Expectação e N. S. da Penha, estes últimos são os nomes presentes na documentação para se referir as vilas (PINHEIRO, 2005, p. 55).

Conforme avançamos no estudo propriamente administrativo, observamos a concordância local com as ordenações em algumas localidades, tais como a instituição de um Juízo próprio para os órfãos e a duração do mandato desse mesmo por três anos: "nes/ta Real Villa do Crato da Com/marca Capitania do Siara / Grande em Cazas de Morada / do Trienal Juiz de Orffon o Ca/pitam Joze Gomes de Mello" (APEC. $1^{\circ}$ Cartório de Órfãos. Cx. 03. No 006. Crato, 1810. p. 26 v). Entretanto, a disseminação do juizado de órfão não foi nem geral para toda a Capitania, nem totalmente conforme essa mesma lei, uma vez que é possível encontrar nos documentos a atuação de juízes ordinários, mesmo depois da criação do juízo específico em várias localidades, atuando nas questões referentes aos órfãos: "nesta vi-/lla de Sancta Onez do Aracati, Capitania do Ceará / grande em cazas de morada do Juiz Ordinario / oCapitão João Dias Martins" (APEC. $1^{\text {o }}$ Cartório de Aracati. (S/n) Inventário de Jose da Costa Moreira. Aracati, 1812. p. 01). Ou, ainda, a assunção de outros juízes, como os juízes de fora, de mais essa atribuição, isto é, a acumulação de funções: "neste Sitio da Baixa grande termo / da Villa do
Aquiras em Cazas de / morada do Juis de [F]ora e orfaons / Francisco Ramos de Freitas" (APEC. $1^{\mathrm{o}}$ Cartório de Órfãos. Cx. 03. № 07. Aquiraz, 1821. p. 01 v).

Uma explicação para essa irregularidade pode ser proveniente da própria organização socioeconômica local, uma vez que acreditamos ser mais fácil termos em Aracati um juiz específico do que num termo da Vila do Aquiraz, ainda que esta também possuísse significativa relevância para o desenvolvimento local, já que o foco da administração era nos locais de maior circulação de produtos do comércio; bem como no primeiro haver um acúmulo de cargos diante da falta de letrados locais, como vislumbramos a partir dos componentes dos inventários os quais contam com grande número de pessoas, homens e mulheres, que assinam em cruz por "naõ / saber Ler, nem escrever" (APEC. $1^{\mathrm{o}}$ Cartório de Aracati. (S/n) Inventário de Jose da Costa Moreira. Aracati, 1812. p. 01). Como destacou Menezes (1966, p. 352), isso não era incomum no período colonial:

[...] êste mestre-escola presta juramento como escrivão da Câmara, tabelião público, judicial e notas, escrivão do crime, civil e órfãos e almotaceria, nomeado pelo juiz ordinário Manuel Félix de Azevedo. O que denota como eram escassos os alfabetizados para êsses cargos, todos nos ombros de um só.

A questão da pouca oferta de letrados e, consequentemente, do acúmulo de cargos, é resultado do próprio contexto de colonização tardia da Capitania do Ceará, tal como aparece em um inventário: "Es/ crivam de seu Car[g]o adiante nomi/ado me achava e [s]endo ahi pelo di/to Juiz em fal[ta] de letrado foi / nomiado para $\mathrm{C}[\mathrm{u}]$ rador ad literao / dos Orfãos deste [Ca]zal" (APEC. $1^{\circ}$ Cartório de Órfãos. Cx. 03. N 05.

${ }^{3}$ V.a é uma abreviação de Vila. 
Aquiraz, 1809). Ademais, Djacir Menezes (1966, p. 353-354) afirma que: “A própria vida social da colônia não era mister de grande número de indivíduos alfabetizados: grande parte das atividades requeridas nas unidades humanas prescindia dos conhecimentos de leitura e escrita". A diferença na instalação do juizado e sua relação com a falta de letrados é apenas uma dimensão dentre uma variedade de situações encontradas nas fontes do período, pois, segundo Vainfas (2001, p. 18), “O funcionamento da administração colonial na América Portuguesa revela a forma complexa e contraditória através da qual a sociedade colonial se constituiu" (VAINFAS, 2001, p. 18).

De uma maneira geral, observando a atuação tanto dos juízes de órfão, quanto dos juízes ordinários, temos certa constância nos documentos cartoriais acerca dos órfãos, os quais iniciam, quando completos, com o auto de inventário, nos quais são especificados o ano, local, data e os responsáveis pela feitura, nesse caso o juiz e o escrivão do documento, seguidos do nome da ou do suplicante, os quais explicitam o ano da morte do inventariado, o número de filhos deixados com suas respectivas idades, assim como os bens a serem inventariados, tudo isso sob juramento dos Santos Evangelhos, conforme a lei orienta:

[...] se proceder a inventa/rio dos bens ficados por óbito / de Francisca Antonia daSil/[va] cazada que [foi com André] / [sic] vidal de negreiros por / lhe averem ficado filhos de me/nor, e para eu escrivao mandou / o dito juiz vir a sua prezen$\mathrm{ca} /$ ao dito viuvo Andre vidal e lhe / deferio o juramento dos Sanctos / Evangelhos (APEC. $1^{\circ}$ Cartório de Órfãos. Cx. 03. $\mathrm{N}^{\mathrm{o}}$ 01. Aquiraz, 1800. p. 4 e 4v).

A partir desse juramento fica confirmada a apresentação de todos "os bens de seo $\mathrm{Ca} /$ zal ficados por obito da dita / sua molher sem ocultar couza / alguas e na de incorrer nas / da lei de perjuro e sunegados / e de pagar aos orfaons Seos / filhos o noviado da lei” (APEC. $1^{\circ}$ Cartório de Órfãos. Cx. 03. No 01. Aquiraz, 1800. p. 4). Além disso, é necessário dizer se há ou não testamento "para se dar cum/primento as suas desposiço/ ens" (APEC. $1^{\circ}$ Cartório de Órfãos. Cx. 03. № 01. Aquiraz, 1800. p. 4v). Para o caso de haver testamento, é através dos desejos do falecido que a partilha é feita, isto é, conforme "Sua /ultimaederadeira vontade" os Juízes agirão nomeando tutores, curadores, além da própria partilha dos bens (APEC. $1^{\circ}$ Cartório do Aracati. (S/n). Inventário de Manoel de Oliveira Porto, 1800). É o próprio falecido que o pede em testamento "minha Ultima von/tade que meus testamentei/ros [sic] deem cum/primento aos meus legados e des/ pusiçons" (APEC. $1^{\circ}$ Cartório de Órfãos. Cx. 03. $\mathrm{N}^{\mathrm{o}}$ 006. Crato, 1810).

Tendo ou não testamento, o passo seguinte é o Termo de Curador, no qual alguém é "nomiado para curador dos me/nores" (APEC. $1^{\circ}$ Cartório de Órfãos. Cx. 03. $N^{o}$ 006. Crato, 1810. p. 5) ou Termo de Tutela onde "o sobredito Juiz / de Orffaos nomiou para Tutor" (APEC. $1^{\circ}$ Cartório de Órfãos. Cx. 03. N 006. Crato, 1810), a este sucede outros termos: dos avaliadores, dos partidores, de seus juramentos, de Conclusão, de data de publicação, além do inventário de partilha de bens, do livro de protesto e dos custos do inventário.

É importante descrever como um inventário desses é feito para percebermos algumas coisas: esses documentos seguem um padrão diplomático que revela $o$ papel da lei e da moral católica intervindo em diversos aspectos da vida, inclusive exigindo ratificações através de juramentos, sugerindo, assim, a importância da Igreja, ao rogar por ela e seus sacramentos, bem como revela a confusão presente entre ela e o Estado, por este período imbricado em relações de poder. Isso tudo pode 
ser vislumbrado, ainda que nem todos os documentos contenham os itens citados.

Ademais, a própria estrutura documental expõe o papel do órfão, enquanto ser submetido ora ao pai ou ao tutor, ora ao Estado; e por fim, diante dos seus custos, revela que o órfão documentado é aquele que provém de famílias de posses ${ }^{4}$, uma vez que o valor do inventário é calculado pelo número de páginas e pagamento dos custos envolvidos no processo, no caso deste específico foram $2 \$ 650$ (dois contos e seiscentos e cinquenta reis) (APEC. $1^{\circ}$ Cartório de Órfãos. Cx. 03. N 01. Aquiraz, 1800. p. 4 e 4 v). Sem contar com o fato de que a própria Ordenação deixa claro que tal status jurídico estava intimamente relacionado com a partilha de bens, ao prever: "Se a herança he tão tênue que seria absorvida com as despezas do mesmo inventário, não se deve fazer" (CÓDIGO FILIPINO, 2004, p. 554).

Além dessa estrutura comum aos documentos coloniais, o estudo de seus dados, tomando como base 23 inventários, com oitenta e cinco órfãos, distribuídos entre os anos de 1800 e 1821, revela que a média da idade dos órfãos documentados no período em estudo varia de dois meses a dezessete anos: na maioria dos casos, encontramo-los entre os intervalos de seis a nove anos, bem distribuídos entre os dois sexos (ASSIS, 2013, p. 124). Já os órfãos, entre o intervalo de nove a dezessete, são em maioria do sexo masculino, o que pode estar relacionado ao direcionamento para o casamento, sobretudo das órfãs, explicitado pelo grande número de herdeiras, nome esse dado ao filho(a) maior de vinte e cinco anos, quando é casado ou emancipado por lei. Os chamados herdeiros são também aqueles que podem participar diretamente do inventário ou indireta- mente, através de seus representantes, denominados 'coherdeiros', os quais agem na sua quase totalidade em nome das esposas herdeiras (Idem.).

O que podemos sugerir do perfil do órfão na Capitania do Ceará, com base na leitura da documentação e dos dados, é que eles recebiam tal status jurídico quando perdiam os pais, dentro dos intervalos supracitados, que ora requeriam cuidados tais como educação e moradia, ora numa idade em que já poderiam requerer carta de emancipação ou contrair matrimônio. Não é por acaso, pois, que poucos são os que chegam aos vinte e cinco anos sem estarem casados, especialmente as mulheres, as quais, independente de atingirem a maior idade, aparecem como herdeiras e representadas pelos maridos. Sobre os juízes, sua atuação está em consonância com a tentativa de dar um novo direcionamento ao pátrio poder, feito principalmente na pessoa dos tutores para as questões dos órfãos, e curadores, para os seus bens.

\section{Entre as práticas e as leis: a formação das famílias dos órfãos}

Conforme sugerimos, o órfão do período de 1799 a 1822 que aparece na documentação da Capitania do Ceará era filho de alguém de posses. Segundo as Ordenações, ele tinha o direito de receber a herança deixada pelo falecido e/ou falecida; nesse sentido, a questão que emerge na transferência desta herança é a capacidade do herdeiro de assumir a frente dos negócios deixados pelo falecido, sobretudo, para os casos em que morre o pai, uma vez que, no caso da morte da mãe, aquele pode assumir, enquanto essa é

\footnotetext{
${ }^{4}$ Como sinalizamos na introdução desse artigo, é possível ampliar o escopo da pesquisa ao incluir os autos de querela, nos quais os órfãos de famílias sem posses aparecem recebendo tutores para resolver situações de conflitos envolvendo crimes. Há todo um conjunto de questões diferenciadas que são utilizadas nesses casos e que também envolvem a ideia de poder paterno e tutoria, nesse caso específico, notadamente voltado para a imposição de uma disciplina de trabalho, como os casos de dá-los a soldada.
} 
considerada incapaz, salvo algumas exceções, como demonstram os atuais estudos sobre mulheres (Cf. ASSIS, 2013).

Olhando para as famílias coloniais, temos notícias de mortes de crianças por doenças, infanticídios, maustratos, abandono, etc.. A questão que nos inquieta é o oposto dessa situação, é entender qual o destino das crianças cujos pais morrem, bem como o papel do Estado diante desses sujeitos visto a partir da legislação como incapaz de gerir-se sem tutores, conforme já mencionado, uma vez que a Igreja não dispunha de nenhuma ajuda para com os órfãos nessa capitania, segundo Capistrano de Abreu: "Das fazendas, terras, lavouras e propriedades possuídas das religiões nem Sua Magestade tem tributos [...] nem as pobres órfãs e viúvas têm esmola alguma; só são úteis às religiões que as possuem e não a outra pessoa alguma" (ABREU, 1998, p. 137). Nesse sentido, na capitania do Ceará, em meados do processo de colonização, era a família a responsável pela criação dos menores, quando das mortes dos pais. Esse cuidado ficava a cargo de outros parentes e até mesmo de pessoas "de bem" da própria Vila.

Vários historiadores apontaram para a importância do estudo da família na organização da sociedade, seja montagem e funcionamento das atividades econômicas, seja nas relações sociais e políticas mais gerais (FARIA, 1997), caminhando nos últimos anos para uma concepção cada vez mais crítica acerca do caráter multifacetado das formas que assumiam, para além da família nuclear, da consaguinidade e do domicílio: “A ampliação desse universo, para além do núcleo constituído por pais e filhos e/ou co-residentes, englobando a parentela, ganhou cada vez mais atenção dos estudiosos" (SCOTT, 2014, p. 14). De maneira que, no contexto de colonização, um dos aspectos preponderantes foi a iniciativa particular, a serviço ou não do Estado, e ligada ou não à Igreja, assim como o fato de que "A organização familiar indicou que os projetos de vida eram pensados muito mais em termos coletivos do que individuais" (BRÜGGER, 2007, p. 23).

Acerca do tratamento destinado aos órfãos, nesse sentido, não foi diferente. As formas de organização familiar provenientes da análise dos inventários e Autos de Querela evidenciam não só o aspecto coletivo da atuação dos sujeitos diante das mais variadas situações, mas também uma gama diferenciada de estratégias usadas para fazer frente ou não aos dispositivos jurídicos com os quais se confrontavam.

A estrutura judiciária deixava a cargo do juiz de órfão resolver, com base nas Ordenações, como a família do órfão se reorganizaria após a morte de um dos seus gestores. Conforme sugerimos no tópico anterior, a legislação previa tanto a tutela, quanto a curatela como as melhores formas de reintegrar esse órfão na sociedade, tendo em vista que elas lhes garantiam tanto o recebimento de uma boa educação, quanto o amparo e cuidado dos bens até atingirem a maioridade. Entretanto, segundo as Ordenações de 1603, também estava ao cargo das Câmaras Municipais a criação das crianças abandonadas em geral, através de tributos específicos, em virtude da morte dos pais ou do abandono por elas, como no caso dos expostos, analisados por Marcílio (2004, p. 27), ainda que ele destaque que neste último caso: "No Brasil raras foram as Câmaras que mantiveram a criação dos pequenos abandonados. [...] E quando o faziam, estava-se longe do atendimento a todos os necessitados".

Especificamente sobre os órfãos, Negrão (2004) aponta várias práticas ligadas à doutrina cristã que visavam ao adestramento e à criação de órfãos desde Portugal, como exemplifica através dos colégios dirigidos por confrarias no século XVI, e pequenas 
iniciativas particulares posteriores já na América Portuguesa, como na Bahia e na Santa Casa do Rio de Janeiro no século XVIII, também através do trabalho de padres. Segundo Barbosa (2005), através da análise do órfão na tradição justiniana, essas e outras atividades desempenhadas pela Igreja estavam em consonância com a figura a ele associada de pobre por enfermidade ou atrelado à noção de preguiça e indolência, de maneira que a condição para receber ajuda, indo além da moral cristã, era estar dentro das leis, do contrário deveria ser castigado.

Sem estarem na condição de expostos, ou sem existirem, num primeiro momento, estruturas católicas para seu atendimento, na Capitania do Ceará, os órfãos não só recebiam tal estatuto jurídico através dos juízes de órfãos, como ficavam aos cuidados deles, seguindo ainda que irregularmente - as disposições das Ordenações. Esses direcionavam seus destinos através da tutoria e da curadoria, uma vez levados em sua "prezensa na forma do Direi/to" (APEC. $1^{\circ}$ Cartório de Órfão. Cx. 03. N ${ }^{0}$ 05. Aquiraz, 1809), mediante a escolha daquele que melhor desempenharia estes papéis, notadamente dentre as pessoas mais próximas da família em questão, chamando a sua presença para a assinatura dos respectivos termos. No caso da morte da mãe, comumente o próprio pai era notificado:

[...] aChava e sendo asi vejo Andre Vidal / de Negreiros por ter cido por mim / notificado para vir asinar termo / de tutoria ao qual o dito Juiz fes in/trega dos orfaons seos filhos de/Clarados no Rosto deste Inven/tario, e dos bens e suas ligitimas /Recomendando lhe que zellace / os ditos orfaons e bens Como he/ra obrigado (APEC. $1^{\circ}$ Cartório de Órfãos. Cx. 03. № 01. Aquiraz, 1800).

Além do termo de tutoria assinado por familiar mais próximo, o juiz podia indicar ainda uma outra pessoa para assinar o termo de curadoria, ficando responsável especificamente para organizar a herança deixada pelo(a) falecido(a), em articulação com as demandas levadas pelo tutor: "Juiz foi [nomiar] / para Curador do menor [...] / ao ad'vogado $\operatorname{Fr}[$ ancisco] / da Costa Coelho / [...] tudo quanto neste mesmo / Inventario fosse a bem e sua Jus/tissa, e Recebido por elle dito Jura/mento sendo prometeo fazer Como the / hera inCarregado" (APEC. $1^{\circ}$ Cartório de Órfãos. Cx. 03. $N^{o} 02$. Aquiraz, 1804). Diferente do primeiro termo, em que a escolha era feita observando a própria estrutura disposta em torno do órfão, neste caso específico, a escolha recaía geralmente em um magistrado ou pessoa letrada do local, dentre os quais é possível encontrar capitães ou até os próprios juízes. Ainda que tal nomeação fosse mais corrente para os casos em que a mãe era a inventariante, por falecimento do pai, em cuja maioria dos casos os tutores eram tios e avôs dos órfãos, ou outros homens mais próximos da família.

Desse modo, fica nítido que, no período colonial, esses dois cargos estavam nas Ordenações, e de certa forma, na prática jurídica local, submetidos ao juiz de órfão. Assim, além da obrigação por lei de tomar para si o destino do órfão, em alguns casos, eles assumiam, inclusive, outros papéis, como no inventário de Antonio Dias Freire, em que ele era cabeça de cazal por conta da morte de sua esposa e, quando ele veio a falecer, o juiz assumiu como curador e nomeou o tio dos órfãos como tutor (APEC. $1^{\circ}$ Cartório de Órfãos. Cx. 03. $\mathrm{N}^{\mathrm{o}}$ 05. Aquiraz, 1809). Ademais, a própria legislação previa sua intervenção quando entendesse que o órfão se encontrava desamparado do pátrio poder, como no caso do "Juiz dos Orfãos achar, que algumas pessoas criaram alguns Orfãos pequenos, sem levar por sua criação algum preço" (CÓDIGO FILIPINO, 2004, p. 211). Podia, inclusive, reorganizar as nomeações e fazer novos termos. 
Neste e em outros casos, além de serem nomeados pelos juízes, os tutores e curadores deveriam recorrer ao mesmo juiz para todas as outras questões referentes aos seus tutelados e a seus bens: "E todo o dinheiro, que os Orfãos tiverem, por lhes ficar por fallecimento de seu pai, ou mãi, ou de dividas, que se lhes devam, ou rendimentos de sua fazenda, tanto que for na mão do Tutor, elle será obrigado a logo requerer ao Juiz.’(CÓDIGO FILIPINO, 2004, p. 216). O que abriu margem para toda uma série de usos indevidos dos bens dos órfãos, seja por parte dos próprios juízes, seja dos tutores e curadores (Cf. ASSIS, 2013). Uma vez que era ele quem determinava até as pessoas que podiam utilizar os serviços dos menores em trabalhos ou no ensino de ofícios, normalmente para onde eram destinados os órfãos do sexo masculino, já que, novamente por lei, "defendemos que nenhuma pessoa, de qualquer qualidade que seja, não tome nenhum Orfão, nem se sirva delle no lugar, onde tiver seu Tutor, ou Curador, se lhe ser dado pelo dito Tutor, ou Curador com autoridade do Juiz dos Orphãos" (CÓDIGO FILIPINO, 2004, p. 212).

Sobre essas duas maneiras de cuidar dos órfãos e seus bens, recorrentes nos documentos analisados e dispostos pela legislação lusa, algumas práticas são confusas e se misturam, pois, como salientou André (2007, p. 15):

\section{[...] não encontramos clareza entre a perfeita distinção entre tutela e curatela, sendo esta última encontrada tanto para os órfãos como para os incapazes, sendo certo que, o "Juiz dos Órfãos" deveria nomear tutor ou curador dentro de um mês, entregando a estes todos os bens que pertenciam ao orfão para adminsitrá -los, caso não tenha ocorrido nenhuma disposição de vontade deixada por testamento.}

No próprio processo de nomeação, ainda que as recusas girassem em torno de uma série de estratégias e estivessem ligadas ao montante disponível na herança dos órfãos em questão (Cf. ASSIS, 2013), entravam também os lugares sociais destinados a mulheres e homens na sociedade colonial, pois, ainda que mesmo nos casos envolvendo homens, a autoridade jurídica prevalecesse: "Fique entendendo q.e o Pay / dos Orfãos não asina termo de Totella de / quem a Lei e não o Juiz o fez Tutor" (APEC. $1^{\circ}$ Cartório de Órfão. Cx. 03. N ${ }^{\circ}$ 01. Aquiraz, 1800); esses tinham a prerrogativa de deixar por testamento suas disposições. Assim, além da nomeação pelo juiz ou da indicação do pai, existia ainda uma terceira forma de articular o destino dos órfãos: a legítima exercida por parentes. Sobre essas formas, Azevedo (1994, p. 24) resume:

De acordo com a legislação, havia três
tipos de tutela: testamentária (quando o
pai antes de falecer já deixava definido
em seu testamento a pessoa que ele
queria que tivesse a guarda da criança.
Isto normalmente acontecia nas familias
de posses); dativa (quando ela era
imposta ou dada pelo juiz na falta de
tutor testamentário e quando não havia
parentes na condição de exercê-la); e
legítima (quando existiam pessoas
ligadas ao menor que deveriam, segundo
a ótica do juiz, exercer a tutela. A
preferência recaía principalmente sobre
parentes consangüineos).

Embora não houvesse uma perfeita distinção legal, as Ordenações definiam os papéis de cada um nesse processo, como já discorremos aqui, os quais deveriam, na sequência da nomeação, permanecer vigiados pelos juízes, até que os órfãos atingissem a maioridade ou casassem. Mas, se as leis já não eram claras, a diferença na sua forma de aplicação aumentava, conforme os juízes e demais pessoas em questão estivessem arregimentados ou articulados.

Tanto na própria documentação referente aos juízes de órfãos, como nos autos de querela que envolvem órfãos em situações criminais, entre outras coisas, percebemos articulações para a resolução de problemas 
que envolviam a família e nem sempre seguiam as propostas legais, além de ficar evidente que vários casos fugiam aos juízes de órfãos, nesse segundo conjunto documental, como aqueles filhos de pessoas sem posses que não passavam pelo inventário, ou nos casos em que uma mesma pessoa assumia tanto a tutoria como curadoria, ocasião em que dificilmente recorria ao juiz para saber o que fazer ou como proceder: "Pede auosa Senho/ria Illistrisimo Senhor Doutor/ Dezembargador Ouuidor Geral/ eCorregedor daComarca SeSirua/ nomiar Curador aaosmenores (...) oadminis/trava como Tutor eCurador dele.” (AUTO DE QUERELA. Livro No 33 Ala: 20. Estante: 421. Caixa 4. No 10). Somente nesse documento, o pedido da mudança de tutor/ curador é encaminhado ao Desembargador, visando à administração dos "menores", e, portanto, exemplifica duas disparidades com as ordenações, onde há distinção entre tutor e curador e o direcionamento dos problemas dos órfãos não é feito inicialmente ao Juiz de órfão, ainda que nas querelas coubesse aos Juízes Ordinários resolver tais questões.

Ademais, além dos já citados, há casos em que o Curador é diferente do Tutor e está encarregado dos menores, e não somente dos seus bens: "Certifico que citei estes herdeiros / os maiores de doze e quatorze annos nas / suas próprias pessoas e os menores em / seu Curador deferido he verdade" (APEC. $1^{\circ}$ Cartório de Órfãos. Cx. 03. Nº 05. Aquiraz, 1809). As próprias situações envolvendo a mãe de órfãos e estratégias de permanecer gerindo seus bens e pessoas acenam para a complexidade que envolve a aplicação de dispositivos jurídicos, isso sem falar nas questões que envolvem a escravidão, como encontramos em alguns inventários: "Decla/ro que de minha Escrava / Francisca teve duas filhas", para elas deixou em testamento a liberdade: “cu/ja liberdade the dei pelo [...] quer ser minha filha" (APEC. $1^{\circ}$ Cartório dos Órfãos. Cx. 03. Nº 006. Aquiraz, 1810); ou considerarmos a existência de mais de um casamento e filhos de pais diferentes: "Cazada / antes dele [...] Cujo Matrimonio lhe ficara hum / filho" (APEC. $1^{\circ}$ Cartório dos Órfãos. Cx. 03. N 04. Aquiraz, 1806).

Ademais, partindo do estudo das fontes e da historiografia (SCOTT, 2014; FARIA, 1997), percebemos que a organização familiar sofre transformações de práticas e costumes, influenciados por elementos coloniais, tais como esta em que o juiz nomeia aquele que exercera o poder pátrio e será, consequentemente, o novo pai do órfão: "Joaquim Pereira de / Lucena tutor dos orfãons Retro / por ter sido notificado por mim / Escrivam para vir assinar Tute/la dos ditos orfaons, e dos bens de / locais legítimos Recomendando /lhe Zelar os ditos orfãons como /se fora seo legitimo Pai" (APEC. $1^{\circ}$ Cartório dos Órfãos. Cx. 03. N ${ }^{\circ}$ 05. Aquiraz, 1809). Enfim, na Capitania do Ceará, a documentação evidencia toda uma rede complexa familiar que inclui genros e netos, com filhos legítimos ou não, sendo apontados como herdeiros: "o Genro Herdeiro deste falescido" (APEC. $1^{\mathrm{o}}$ Cartório de Aracati. José da Costa Moreira. Aracati, 1812), além de maridos co-herdeiros que assumem a frente na partilha dos bens destinados as herdeiras do falecido, que muito podem contribuir para a compreensão da História da Família no Brasil.

\section{Considerações finais}

O objetivo do artigo foi problematizar o lugar dos órfãos no período colonial, a partir da documentação da Capitania do Ceará e das Ordenações Filipinas, bem como ressaltar as disparidades entre o que propunha a legislação lusa e as práticas na colônia. $\mathrm{Na}$ primeira parte, vimos que a existência do juizado de órfãos no Ceará estava em consonância com o processo de colonização e organização do comércio das vilas e cidades 
da própria Capitania, o que teve impacto na própria disposição da documentação existente para a análise do período colonial, desde a emancipação da Capitania de Pernambuco em 1799, até 1822. Além disso, a feitura do inventário conforme a existência de bens e os sujeitos envolvidos no processo interferiram na nomeação de tutores e curadores aos órfãos, entendidos aqui como categoria jurídica cunhada a partir do trabalho desenvolvido pelos juízes de órfãos e especificada pelas Ordenações Filipinas, para aqueles sujeitos menores de 25 anos de idade que eram entendidos como incapazes de gerir seus bens e pessoas.

Em seguida, observamos que, nesse local e período, a família estava no cerne da questão da criação dos menores quando da morte de um dos pais, o que tinha resultado diferente conforme fosse a mãe ou o pai o ente falecido: no primeiro caso, o próprio pai assumia a tutoria do filho, embora o curador pudesse ser outra pessoa da localidade ou até mesmo o juiz de órfão; no segundo, existindo ou não um direcionamento testamentário, a tendência era que a tutoria recaísse sob a responsabilidade de um dos homens da família ou parentes próximos, notadamente tios e avôs.

Nesse sentido, a tutoria e a curadoria podem ser vistos como dispositivos jurídicos usados para dar destino aos bens e pessoas dos órfãos, dentro da ideia de pater potestas (poder paterno), de modo que o destaque ficava por parte do trabalho desempenhado pelos juízes de órfãos e seus direcionamentos ao longo desse processo. Aliás, conforme dicionário do período, a própria ideia de família estava intimamente relacionada ao exercício do pátrio poder: "as pessoas, de que se compõe a casa, e mais propriamente as subordinadas aos chefes, ou pais de familia. $\S$ Os parentes, e alliados. $\S$ Filho familias t. jur. o que está sob o patrio poder" (BLUTEAU, 1728, p. 597); assim como a ideia de órfão estava tanto relacionada "a quem morreu o pái ou a mãi", quanto ao "Desamparo em que deixa a fala dos pais" (Idem, p. 610 e 611).

Assim, apesar das disparidades entre leis e práticas, o que pudemos inferir foi que o juizado de órfão foi uma tentativa legal de "substituir o poder familiar diante das pessoas cujos pais faleceram, não se fazendo referência ainda sobre a destituição ou suspensão desse poder" (ANDRÉ, 2007, p. 15). O que não significa dizer que ele não foi atravessado por arranjos diferenciados, estratégias e negociações. Desse modo, se o juizado de órfãos foi organizado visando à constituição de uma nova família ou sua organização depois da morte de um dos pais, ainda que fosse por tempo limitado, até a maioridade dos órfãos, regido a partir do pátrio poder, e tomasse a forma na nomeação de tutores e curadores, inclusive sendo a instituição da tutela, como destacou Cardozo (2010, p. 5), "um dos instrumentos empregados por este órgão jurídico para regulamentar a família", os arranjos familiares não tomavam a forma apenas dentro dessa instituição jurídica. De fora e para além dela várias questões podem ser vislumbradas, assim como a própria ideia de família assume diferentes matizes, conforme adentramos numa ou noutra documentação, de maneira que esperamos ter deixado evidente a riqueza de pesquisar não somente com inventários, como vários pesquisadores vem sugerindo (FARIA, 1997; SCOTT, 2014), mas de observar as próprias questões que envolve ser órfão no período colonial. 


\section{Referências bibliográficas}

ASSIS, Patrícia Marciano de. Entre leis e práticas: família e cotidiano dos órfãos na capitania do Ceará. Monografia apresentada a Universidade Estadual do Ceará, Fortaleza, 2013.

ABREU, Capistrano de. Capitulos de história colonial: 1500-1800. Brasília: Conselho Editorial do Senado Federal, 1998. 226p. (Biblioteca básica brasileira).

ALMEIDA, Cândido Mendes de. Código Filipino, ou, Ordenações e Leis do Reino de Portugal: recopiladas por mandado d'el-Rei D. Filipe I. Ed. fac-similar da $14^{\text {a }}$ ed., segundo a primeira, de 1603, e a nona, de Coimbra, de 1821. Brasília: Senado Federal, Conselho Editorial, 2004.

ALGRANTI, Leile Mezan. "Famílias e Vida Doméstica". In: História da Vida Privada no Brasil: Cotidiano e Vida Privada na América Portuguesa. São Paulo: Companhia de Letras, 1997.

ANDRE, André Luiz Pedro. As ordenações e o direito privado brasileiro. Revista eletrônica da Faculdade de Direito de Campos. Campos dos Goytacazes, RJ., v. 3, n. 3, out. 2007. Disponível em: http://www.fdc.br/Arquivos/ Revista/31/01.pdf. Acesso em: 23/08/2011.

AZEVEDO, Gislane Campos. "De Sebastianas e Geovannis”: o universo do menor nos processos dos juízes de órfãos da cidade de São Paulo (1871 - 1917). Dissertação apresentada a Pontifícia Universidade Católica, São Paulo, 1995.

BARBELO, Avelar. apud. PINHEIRO, Francisco José. Solo fértil na Capitania: um projeto para o Ceará em fins do século XVIII. DOCUMENTOS: Revista do Arquivo Público do Ceará: Ciência e Tecnologia. Fortaleza, v.1, 2005 .

BARBOSA, Rosa Alves Ferreira. Fronteiras sociais e culturais: a infância desvalida e suas formas de "proteção". In: Territórios e Fronteiras. Cuiabá, MT., v. 6, n. 2, jul./dez., 2005.

BICALHO, Maria Fernanda Baptista. Crime e Castigo em Portugal e seu Império. In: Topoi. Rio de Janeiro, n. 1, 2000 .

BLUTEAU, Raphael. Vocabulario portuguez \& latino: aulico, anatomico, architectonico ... Coimbra: Collegio das Artes da Companhia de Jesus, 1712 - 1728.

BRÜGGER, Silvia Maria Jardim. Minas patriarcal: família e sociedade (São João Del Rei - Séculos XVIII e XIX). São Paulo: Annablume, 2007.

CARDOZO, José Carlos da Silva. O juizado de órfãos e a organização da sociedade nos anos iniciais do século XX. Revista História em Reflexão. Vol. 4. n. 8. UFGD. Dourados Jul/dez, 2010.

CARDOZO, José Carlos da Silva. Na fronteira da família: entre a lei e a moral. Em tempos de Histórias - Publicação do Programa de Pós-Graduação em História da Universidade de Brasília PPG-HIS, nº 17, Brasília, ago/dez. 2010 .

FARIA, Sheila de Castro. História da Família e Demografia Histórica. In: VAINFAS, Ronaldo; CARDOSO, Ciro Flamarion (orgs.). Domínios da História: ensaios de teoria e metodologia. Rio de Janeiro: Campus, 1997.

FREYRE, Gilberto. Casa-Grande \& Senzala. Rio de Janeiro: Record, 2000.

GALLO, Alberto. "La venalidad de oficios públicos en Brasil durante el siglo XVIII". In: BELLINGERI, Maco (coord.). Dinámicas de Antigu Régimen y orden constitucional representación, justicia y administración en Ibeoamérica, siglos XVIII-XIX. Torino: Otto Editore, 2000.

GIRÃO, Valdelice Carneiro. As oficinas ou charqueadas no Ceará. Fortaleza: Secretaria de Cultura e Desporto, 1984.

MARCÍLIO, 1993, apud, NEGRÃO, Ana Maria Melo. Infância, educação e direitos sociais: "Asilo de Órfãs". Campinas, SP: UnicampcCmu, 2004.

MENEZES, Djacir. A educação no Ceará: Repasse histórico-social (das origens coloniaia a 1930). In: FILHO, Antonio Martins. GIRÃO, Raimundo. O Ceará. 3ed. Fortaleza: Editora Instituto do Ceará, 1966. 
MORENO, Alessandra Zorzetto. Vivendo em lares alheios!" acolhimento domiciliar, criação e adoção na cidade de São Paulo (1765 - 1822). Campinas, SP: [s. n.], 2007. Tese de doutorado pela Universidade Estadual de Campinas, Intituto de Filosofia e Ciências Humanas.

NEGRÃO, Ana Maria Melo. Infância, educação e direitos sociais: asilo de órfãs (1870-1960). São Paulo: Unicamp/CMU, 2004.

PINHEIRO, Francisco José. Solo fértil na Capitania: um projeto para o Ceará em fins do século XVIII. DOCUMENTOS: Revista do Arquivo Público do Ceará: Ciência e Tecnologia. Fortaleza, v.1, 2005.

QUEIROZ, Maria Isaura Pereira de. O mandonismo local na vida política brasileira e outros ensaios. São Paulo: Editora Alfa-ômega, 1976.

SALGADO, Graça (coord.). Fiscais e meirinhos: a administração no Brasil Colônia. Rio de Janeiro: Nova Fronteira; Brasília: INL, 1985.

SCOTT, Ana Silvia Volpi. "Descobrindo" as Famílias no passado brasileiro: uma reflexão sobre a produção historiográfica recente. In: História da Família no Brasil Meridional: temas perspectivas. São Leopoldo: Oikos; ditora Unisinos, 2014.

SILVA, Sheyla Farias. Entre letras, pontos e agulhas: a educação de órfãos na Estância - SE oitocentista. Historien, Petrolina, jan./mar., 2010

VAINFAS, Ronaldo (org.). Dicionário do Brasil colonial (1500 - 1808). Rio de Janeiro: Objetiva, 2001.

VIEIRA JÚNIOR, Antonio Otaviano. Entre paredes e bacamartes: história da família no sertão (1780-1850). Fortaleza: Edições Demócrito Rocha, Hucitex, 2004.

Submissão: 23/03/2018

Aceite: $02 / 10 / 2018$ 